\title{
Re-thinking the Promotion of Women's Rights through Islam in India
}

\author{
Nida Kirmani
}

Abstract Religiously framed approaches to women's rights advocacy, which include those that utilise religious discourses or work through religious leaders and institutions, have increasingly been adopted by a variety of actors, particularly in Muslim contexts. While the use of such approaches may often be an effective means of advocating for reform of laws on women's rights that are founded on principles deriving from religious jurisprudence, there remains a need for critical analysis of such engagements. This article examines the experiences of two Muslim women's rights networks in India, the Muslim Women's Rights Network and the Bharatiya Muslim Mahila Andolan, both of which have attempted to work with religious institutions and through religious framings in order to secure women's matrimonial rights. This case study highlights both the possibilities and limitations of adopting religiously framed approaches and argues that the strategies of women's rights advocates must be grounded within political and social realities without being either essentialist or exclusionary.

\section{Introduction}

Recent years have witnessed a growing awareness of the importance of taking religion into consideration within development initiatives, including in those related to gender equality. A variety of actors including donor agencies, transnational development organisations, and local women's rights activists are increasingly using religiously framed approaches such as utilising religious discourses (e.g. texts, symbols and language), and/or working through religious actors (e.g. religious leaders and institutions) as a means of promoting women's rights particularly in Muslim contexts. This trend has grown out of a combination of factors including the increasing awareness of the importance of religion and culture in development, the emergence over the past two decades of various forms of Islamic feminism(s) around the world, as well as a sense that any social change in Muslim communities can only take place within the framework of Islam. However, despite the recent moves to reconcile religion with women's rights, little effort has been made to critically analyse the implications of such approaches.
This article attempts to do this, first by contextualising the increasing use of religiously framed approaches to Muslim women's rights by development actors within a wider discussion of the relationships between women's rights struggles and religion in general and the growth of Islamic feminisms in particular, in various parts of the world. It then looks more closely at the experiences of Muslim women's rights activists in India, focusing particularly on the strategies of two networks: the Muslim Women's Rights Network (MWRN) and the Bharatiya Muslim Mahila Andolan (BMMA). Both networks have engaged positively with Islam at different times and to differing extents through the promotion of the 'woman-friendly' nikahnama (marriage contract) and by engaging with the All India Muslim Personal Law Board (AIMPLB). Through this case study, the article aims to look critically at the possible advantages and limitations of engaging with Islam as part of women's rights advocacy strategies and asks how far such strategies can go in changing entrenched gendered power structures. 


\section{Background: using religious framework to promote women's rights}

Advocates of women's rights have for long questioned religious traditions, beliefs and institutions as part of their struggles for gender equality, leading to a perceived antagonism between religion and women's rights (Phillips 2009; Winter 2001). At the same time, many feminists and members of women's movements have periodically allied with religious groups or utilised religious discourses in order to promote gender equality, either as a proactive or a reactive strategy. Since the 1980s, there has been a general growth in religious feminisms - or projects that aim to reclaim and reinterpret religion from women's perspectives or in a manner that respects women's rights. Reformist feminist traditions have made great strides in reconciling feminism with faith in a variety of ways and are challenging long-held assumptions about the relationship between women's rights and religion within conservative and orthodox religious circles as well as among secular feminists.

In the case of Islam, there has been a growth in religious feminisms over the past two decades, which can be seen partially as a reaction to the growing strength of conservative Islamist movements around the world, as well as an increasing number of Muslim women becoming scholars of religion. 'Islamic feminists', according to Moghadam (2004: 53), attempt to 'reclaim their religion to undermine both Islamist patriarchal distortions and Western stereotypes of Islam as backwards and terroristic'.

Prominent Islamic feminists include individuals such as Riffat Hassan (2002), Amina Wadud (2007) and Azizah Al-Hibri (2004), who argue that Islam is not the cause of women's oppression, but rather 'culture' and 'patriarchy' are to blame. They contend that Muslim women must reclaim religion from men in order to uncover the truly egalitarian underpinnings of Islam (Hashim 1999).

The emergence of various manifestations of 'Islamic feminism' has not only been significant on a discursive level in terms of expanding the space for debate about gender and Islam, this has also inspired a variety of 'practical strategies' for securing women's rights, which Western donors and transnational development agencies are increasingly promoting as being more effective, 'culturally sensitive' means of advocating for
Muslim women's rights (UNFPA 2004). These approaches include working with religious leaders and institutions as partners in women's rights advocacy campaigns as well as encouraging women to understand and use religious texts and concepts in order to defend their rights. Many women's rights advocates working in Muslim contexts also argue that religion must play an intrinsic role in gender-related advocacy strategies if they are to be acceptable and successful (Adamu 1999). However, apart from the work of a limited number of scholars (e.g. Balchin 2003; Bartelink and Buitelaar 2006), very little critical examination has taken place as to what the underlying assumptions and implications of religiously framed approaches might be, particularly when they are applied to the promotion of Muslim women's rights.

There are several questions that arise when considering the implications of religiously framed approaches to women's rights including: how far can such approaches go in actually changing patriarchal power structures? Are efforts to engage with religious discourses and actors actually bolstering the authority of what are essentially patriarchal institutions and discourses? Or are religiously framed approaches the only realistic means of protecting women's rights in contexts in which communities feel that Islam is under threat? The remainder of this article attempts to think through some of these questions, through an examination of the experiences of two networks in India, the Muslim Women's Rights Network (MWRN) and the Bharatiya Muslim Mahila Andolan (BMMA). This case study will help illustrate the groundlevel complexities of engaging positively with religion as part of women's rights advocacy.

\section{Advocating for Muslim women's rights in India: the MURN and the BMMA ${ }^{2}$}

In India, where Muslims are the largest religious minority, comprising roughly 12 per cent of the population, the issue of Muslim women's rights is particularly sensitive and politicised. 'Muslim women' are constructed as an oppressed 'minority within a minority' (Lateef 1998) by various groups including by Hindu nationalists, the media and academics, who represent Muslim women as a homogenous category with a common set of interests (Kirmani 2009b). The issue of Muslim women's rights became an issue of national debate in the 1980s during the 
landmark Shah Bano case. This case involved a 72-year-old woman who had been divorced and was claiming maintenance from her husband in the Madhya Pradesh High Court. This case, which eventually made it to the Supreme Court, called the system of separate personal laws ${ }^{3}$ into question during a time when religious sensitivities were particularly high. The Hindu nationalist movement, which was growing in strength at the time, used this case to prove that Muslims were 'backwards' and in need of integration into the 'Hindu nation'. The Muslim conservative groups, led by the All India Muslim Personal Law Board (AIMPLB) ${ }^{4}$ reacted by organising massive protests across the country to uphold Muslim personal laws and protect 'the community' from the interference of the state. This put the women's movement, which has been historically dominated by urban, upper-caste women, in a difficult position: if they argued for a universal civil code, they would be aligning themselves with the Hindu Right, and if they argued for the maintenance of personal laws, they would be betraying their secular underpinnings and the rights of Muslim women. The women's movement had to tread a careful path, arguing for reformed personal laws that would protect women's rights. The Congress government eventually passed the Muslim Women (Protection of Rights on Divorce) Act $1986,{ }^{5}$ which effectively exempted Muslim women from the purview of state laws, and maintained the system of separate personal laws. Throughout these debates, Muslim women were themselves largely absent (Chhachhi 1991; Hasan 1994, 1998; Kumar 1994; Kishwar 1998).

Since this time, however, Muslim women-led groups and networks have begun emerging in urban centres across the country, and although they may be relatively few in number, their voices are increasingly gaining national attention through their participation in debates related to Muslim women's rights. Members of networks, such as the Bharatiya Muslim Mahila Andolan (BMMA), which consciously take an 'Islamic feminist' approach and the Muslim Women's Rights Network (MWRN), ${ }^{6}$ which is committed to secular feminism, challenge the dominant construction of the 'oppressed Muslim woman' by presenting themselves as articulate and powerful agents, while continuing to draw attention to the multiple forms of discrimination and exclusion that Muslim women in India face. They rally around the issue of personal laws and women's matrimonial rights, presenting a counter-voice to the conservative position taken by the All India Muslim Personal Law Board, as well as highlighting wider issues faced by Muslim women that have not been addressed by the ulema (scholars of Islam), the state, or in any depth by the mainstream women's movement including religious and gender-based insecurity resulting from communal violence as well as social, economic and political marginalisation and discrimination.

One of the strategies employed by advocates of Muslim women's rights in India as well as in other countries, has been to popularise the notion that women can write or have input in their own nikahnamas (Muslim marriage contracts), particularly in terms of inserting clauses that will secure their rights within marriage. Muslim women's rights activists have proposed the idea of a 'woman-friendly' nikahnama as a means of protecting women's rights without challenging the system of separate personal laws. Many women's organisations including those within the MWRN and BMMA have produced 'model nikhanamas', which differ slightly in their content, but for the most part include provisions to protect women from arbitrary divorce and give them the right to divorce and to claim their mehr, ${ }^{7}$ to prohibit polygamy, and to guarantee women the right to maintenance in the case of divorce. The campaign to protect women's matrimonial rights has taken place at the national level, through lobbying the AIMPLB to agree to reform Muslim personal laws or to produce their own model nikahnama as well as at the local level, through community education and the public performance of individual and group marriage ceremonies using model nikahnamas.

Although women's rights activists have always been critical of the AIMPLB and have questioned its authority, especially since the Shah Bano case, they have also been aware of the influence this body has at the national level because it is seen as a source of religious authority by many Muslims. Naseem, who is based in Delhi and is active in the MWRN, pointed to the positive influence the AIMPLB could have:

If the Personal Law Board puts forward a nikahnama then people will follow it ... if the Network [MWRN] puts out the same nikahnama, people will not use it. 
We put a lot of effort into drafting it, but it's just sitting there. No one is ready to use it because everything that is written in it is in favour of women. (Naseem, 20 September 2008)

For this reason, since the MWRN was created, its members have been lobbying the AIMPLB to agree to a reformed set of personal laws or to adopt the network's model nikahnama or to propose its own version that would protect women's rights. This has mostly been done through letters that documented individual cases of women who were struggling to secure their rights within their marriages in order to illustrate the need for the AIMPLB to address these issues publicly. The AIMPLB did not respond to these letters.

However, in 2001, the Board finally agreed to call a meeting in Delhi, which several members of the MWRN as well as other women's rights activists from across the country were invited to attend. During this meeting, women's rights activists presented their testimonies to the Board, pointing to the lack of legal safeguards for women and the need for reform, especially on the issue of divorce. However, the accounts of many of the activists interviewed who attended the meeting, reflected a fundamental lack of understanding between women's rights activists and Board members, many of whom seemed more interested in the appearance of the women present, being critical of the fact that they were not practicing parda, ${ }^{8}$ rather than the content of what they were saying.

One of the reasons for the lack of progress at the 2001 meeting and subsequently, is a fundamental difference in approach between women's rights activists and the Personal Law Board on the question of religion. SQR Ilyas, who is a member of the AIMPLB as well as being active in Jamaate-Islami, pointed out that the Personal Law Board works within a particular Islamic framework:

The Muslim Personal Law Board cannot do anything that goes against Islam. ... Questions can only arise if you and I have a difference of interpretation between us. The only interpretation of Islam that can be acceptable is the one that Allah and his Prophet and his companions and the people that followed them have agreed upon. There can be no such interpretation that the umma [Muslim community] doesn't have an agreement on.

(SQR Ilyas, 16 December 2008)
Therefore, for example, on the issue of banning triple $t a l a q$ - the practice in which a man is allowed to divorce his wife simply by uttering the words, 'I divorce you' three times - the AIMPLB has refused to take a firm stand against this practice. This is because, although there are differences in opinion on this issue between different Islamic schools of thought, the general consensus among the Indian ulema has been that this practice is frowned upon but not forbidden in Islamic law. Women's rights activists, on the other hand, place women's rights first and argue, either from an Islamic or human rights perspective, that triple talaq should be banned outright because it contradicts the principles of justice and equality.

Furthermore, members of the Law Board pointed out at the meeting that they had no power to change the laws since the Board is not a legislative body and is rather 'just an NGO' like the women's organisations at the meeting. This may have been a convenient way for the AIMPLB to abdicate any responsibility to protect women's rights, but for many of the women's rights activists at the meeting, it was a wake-up call, both because they realised that the AIMPLB does not have any legal powers and because of the Board's perceived unwillingness to engage seriously with their concerns. Nevertheless, people like Naila, who is a member of the MWRN, feel that the AIMPLB has influence despite its lack of statutory powers:

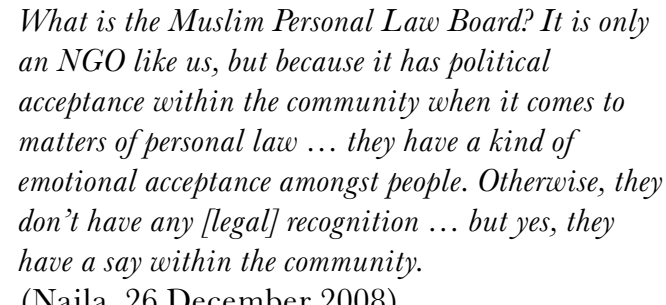

(Naila, 26 December 2008)

Despite their recognition of the AIMPLB's symbolic power, after the 2001 meeting, many women's organisations, including those affiliated with the MWRN, abandoned the strategy of engaging with the AIMPLB.

Noorjehan Safia Niaz, who is one of the founding members of the BMMA, said that, although some still feel that it is worthwhile to work with the AIMPLB, she felt that it would be a 'futile effort':

IDS Bulletin Volume 42 Number 1 January 2011 
We can do so [engage with the AIMPLB] if we have to, but I believe that that energy could be saved for strengthening the community, giving them more information, mobilising them - it is a better use of energy and resources.

(Noorjehan Safia Niaz, 22 September 2008)

Hasina Khan, who is one of the founders of the MWRN, echoed these sentiments, saying that AeN had spent ten years lobbying the AIMPLB with little or no result and have therefore decided to abandon this 'bankrupt strategy' to focus on other forms of lobbying (Hasina Khan, 26 September 2008).

At the same time, the 2001 meeting and the ongoing efforts of women's rights advocates may have prompted processes of change within the AIMPLB by contributing to debates that had already been taking place within the Board on the issue of the nikahnama and on women's rights in general. A draft version of a model nikahnama, produced internally, was first presented within the AIMPLB at a meeting held in Bangalore a year before the 2001 meeting with women's groups. Begum Naseem Iqtedar Ali, who is the first and only woman member of the AIMPLB's Executive Committee, described how the nikahnama was nearly passed by the Board at that time, but was finally rejected over the issue of talaq-e-tafweez, or women's right of divorce:

What happened was that the nikahnama was passed by the Executive Committee, but it also needed to be passed in the General Assembly. During that evening in the place where we were staying, one group of women was against it. There was so much debate and discussion between the two groups ... I just wanted it to be passed, but no one would listen. Those women convinced the rest of the group, so that when it was presented, it was those women who opposed it. What people then said was that if women are themselves opposed to it, then how can we pass it?

(Begum Naseem Iqtedar Ali, 23 December 2008)

Those who opposed the Board's draft nikahnama argued that, including a clause on women's right to divorce would be considered inauspicious at the time of a marriage and it should therefore be left out of the document. Uzma Naheed, who is a member of the General Assembly and who argues for women's rights within an Islamic framework, also pointed out that, of the women members of the AIMPLB, who constitute less than 10 per cent of the Board, few are advocates of women's rights, noting the lack of consensus even among 'religious women' (19 September 2008).

Eventually, the AIMPLB did pass a model nikahnama at a meeting held in Bhopal. However, this nikahnama disappointed many women's rights advocates, both within the MWRN and the BMMA and beyond. Although it did include some 'progressive' features, which addressed the demands of women's groups, including recommending a process of mediation and arbitration before a divorce can take place, discouraging the practice of dowry, recording the amount of mehr to be given to the bride, and including a clause stipulating that a man must get written consent from his wife if he wishes to remarry, it also included some regressive features. For example, the model included guidelines stating that a woman should be obedient to her husband and that she should ask his permission before stepping out of the house. As well, it did not ban the practice of triple talaq and did not include a woman's right to divorce her husband (Katakam 2005). Most women's rights advocates saw the AIMPLB's nikahnama as further evidence of the Board's rigidity rather than a sign of progress. Furthermore, there is no evidence that the Board has gone beyond simply issuing their model nikahnama in terms of actively encouraging its adoption or promoting the concept at the grassroots level among local clerics.

On the other hand, the AIMPLB's effort can also be viewed as a sign of positive change in response to internal processes of change and years of lobbying by women's rights advocates and might thus be seen as evidence of the women's rights activists effecting a transformation of a key religious institution. Naila has studied the AIMPLB's nikahnama closely, and described her mixed feelings about the AIMPLB's efforts:

\footnotetext{
I took it as a positive step because I didn't have any hope that those people [the AIMPLB] would bring out a nikahnama. At least they are issuing some guidelines. Till then they hadn't even done that. Because as a Muslim woman, my question has always been, why do they [religious leaders] talk about the ways you can rule over women and not the rights that women have, when these things are present within Islam? ... If you look at it that way, then for the first time, in the light of Islam, at least they are saying
} 
something about women's rights, but after reading it, I also felt that we are asking for something, and they are benevolently bestowing this upon us, which I don't look at positively.

(Naila, 26 December 2008)

For Naila, the fact that the AIMPLB had made any kind of public statement in relation to women's rights was a step in the right direction and a sign that the Board was changing, however slowly. At the same time, she took issue with the manner in which the nikahnama was presented, as a pronouncement rather than a contribution to a process of dialogue, which was similar to the complaints of women's rights advocates after the 2001 meeting.

\section{Advocating for the nikahnama at the community level: reflections from the field} Apart from lobbying the AIMPLB at the national level, members of MWRN and BMMA continue to promote the woman-friendly nikahnama within local communities across the country. Groups such as Awaaz-e-Niswan, which is part of the MWRN, and the Women's Research and Action Group, members of which are part of the BMMA, in Mumbai educate women and their families about the fact that they can add clauses to a nikahnama as a means of ensuring a woman's security, through individual and group discussions at the local level. The MWRN and the BMMA have also facilitated public weddings using their model nikahnamas, with the wedding of Naish's Hassan, who is one of the leaders of the BMMA, capturing national attention because it was being performed by a prominent woman, Syeda Hameed, and used a model nikahnama (Wajihuddin 2008).

However, although exact figures are not available, most activists acknowledge that the number of marriages that have actually taken place using these model nikahnamas remains relatively limited. There are several possible reasons for this. Yasmeen, who is a member of Awaaz-e-Niswan, said that it is often the qazi (cleric), who performs the ceremony and whose stamp is required to validate the nikahnama, who proves to be the main stumbling block: 'The main problem is that, no matter which nikahnama it is, the qazi is not ready to use it. The first problem is that he himself is a man and all of this is about women's rights' (Yasmeen, 20 September 2008). Over the years, women's groups have identified 'sympathetic' qazis in their localities, who have agreed to perform weddings using the groups' nikahnamas. However, even if the qazi agrees, often the groom's family will raise objections, and in some cases, the bride herself is reported to have refused, possibly out of fear of upsetting her in-laws or her own family by appearing too bold or demanding.

Apart from the practical difficulties of gaining acceptance for progressive nikahnamas, Hasina Khan points to the limitations of nikahnamas as a means of achieving broad-based social change:

As good as a nikahnama is, if a woman can't choose her own partner, if a woman isn't able to speak to her partner and they have no understanding between each other, then what's the point?

(Hasina, 16 September 2008)

She gave the example of women who do not want to get married at all, or who are not allowed to choose their husbands, to illustrate the genderbased restrictions of the wider social context.

Hence, she asserted, although the nikahnama is a tool in the promotion of women's rights, this document alone can do little to transform existing structures of power. Instead, she suggested, it can only provide a degree of protection for women within the current system. At the same time, the fact that the nikahnama does not pose a radical challenge is also most likely the reason that it has been so widely promoted by a range of women's groups and religious organisations.

Despite its limitations and its lack of wide-scale acceptance, the promotion of the nikahnama has been successful in raising general awareness among Muslims on the issue of women's rights. Members of Awaaz-e-Niswan spoke about how the promotion of the nikahnama is beginning to change attitudes among members of the community as well as qazis in Mumbra, a predominantly Muslim area located on the outskirts of Mumbai:

Yes, awareness has been raised. Whether people use the nikahnama or not, they have started to understand what issues they can raise with the qazi. They know that the amount of mehr should be written down. There has been more awareness about these issues through the nikahnama.

(Naseem, 20 September 2008) 
Aqeela, who works as a librarian in AeN's Rehnuma Centre and is also involved in case work and advocacy, added:

What has happened in Mumbra is that many of the nikahnamas that are being used today at least have clear information about mehr, so that if there are problems, at least you have some proof ... if the information about mehr is clear, then you are more likely to receive it ... there are a lot of cases in which the girl has received the mehr that she has been promised.

(Aqeela, 20 September 2008)

Hence, members of the MWRN and the BMMA agreed that the model nikahnama can be an important means of protecting particular women's rights within the current social and legal system in India and in a context where many Muslims, and especially the ulema, feel threatened by any suggested change to Muslim personal laws. They also reported that the nikahnama campaign has been an important means of gaining support and building linkages between women's organisations and with diverse actors, as a result strengthening both the MWRN and the BMMA.

Although the nikahnama can be cited as an example of women's rights activists successfully utilising a concept that fits into an Islamic framework to protect the interests of women, at the same time, its impact has been limited because it is unable to challenge wider social attitudes and structures of power. The fact that the AIMPLB, qazis and women's families themselves are hesitant to adopt a 'womanfriendly' nikahnama reflects the deep-seated nature of patriarchal power structures in Indian society. An analysis of the nikahnama campaign and the engagement of Muslim women's rights activists with the AIMPLB raise wider questions as to how far working within an Islamic framework and within religious institutions can actually challenge patriarchal structures of power.

\section{Conclusions}

Although women's rights activists in Muslim contexts, such as those involved in Muslim women-led networks in India, have been engaging with Islam in diverse and creative ways for decades, the drive to engage with Islam has occurred more recently among international development agencies and often springs from the notion that Muslim women are particularly oppressed and in need of rescuing (Abu-Lughod 2002) and that this can only be effectively achieved through 'internal reform'. The case study of the MWRN and the BMMA demonstrates some of the complexities of negotiating with religious concepts and actors as part of women's rights advocacy that may be instructive for other development actors.

The case study demonstrates some of the advantages of engaging positively with religious discourses and actors as part of women's rights advocacy. Using Islamic concepts such as the nikahnama can effectively deflect accusations of taking a 'Western' or anti-Muslim approach, especially in a context such as the Indian one in which Muslim identity is considered to be 'under threat'. In such situations, it is often necessary for women's rights advocates to use Islamic arguments to counter criticisms. Furthermore, on issues such as personal laws, which in many contexts are based on particular interpretations of Sharia, women's rights advocates have had little choice but to work within a religious framework by presenting alternate interpretations of Islam. Therefore, although model nikahnamas may not be used on a wide-scale in India yet, there is evidence that this campaign is helping to raise awareness in a slow and steady manner about women's rights within Islam.

Furthermore, engaging with religious institutions such as the AIMPLB can create spaces and opportunities for dialogue with those that may otherwise be left out of gender-related initiatives. Working with religious leaders, who are by and large men and who often have access to large numbers of male community members, can be an effective means of involving men in genderrelated advocacy campaigns. Such efforts can help convince those who may otherwise be sceptical of the importance of protecting women's rights and can help stimulate a wider dialogue about gender relations. Hence, although the AIMPLB initially resisted the lobbying efforts of Muslim women's rights activists, ignoring their letters and denying them a respectful hearing during the 2001 meeting, they did eventually release a model nikahnama that, although limited in its scope, can be seen as a first step in protecting women's matrimonial rights.

At the same time, working with and through religious leaders and institutions, such as the 
AIMPLB may also have unintended negative consequences. Approaches that focus on working with religious leaders or that rely on them to communicate gender-related messages run the risk of legitimising their authority within the community rather than challenging structures of power that keep women in subjugated positions. While religious leaders may be influential members of the community, by highlighting their role and seeking their support, as the Muslim women's rights activists had done previously by lobbying for the AIMPLB to change its position, women's rights advocates may be inadvertently validating the power of particular groups of elite men rather than empowering women to claim their own rights. As Pearson and Tomalin (2008) note, the 'rush' to engage with religious leaders and institutions, who often hold conservative positions regarding gender roles and relations as was demonstrated by the AIMPLB's nikahnama, may actually endanger the gains that have been won over the past decades by women's rights activists. This is the conclusion that many Muslim women's rights activists arrived at following the 2001 meeting when they realised that lobbying that particular institution was having little impact. The strategy of denying the authority of religious leaders and institutions and empowering women to take control of their own rights, whether within or outside of an Islamic framework, was seen as a more constructive use of the limited resources of women's organisations.

Apart from the risks involved in engaging with religious actors, Islamically framed approaches, such as the nikahnama campaign tend to privilege what is outlined in religious texts as the only legitimate framework for claiming rights. Mirza (2008: 31) points out that by privileging textual approaches to Islam, ironically, Islamic feminists follow the same methodological lines as Islamists: 'both are anchored in the central texts of the Quran and the hadith literature; both represent their own interpretation as the expression of authentic or 'true' Islam; and both discourses have appropriated the notion of the ideal past of Islam as the foundation of law'. Hence, Islamic approaches to women's rights advocacy can inadvertently reinforce the notion that the lives of Muslim women must be governed solely by religious precepts and that women must work through Islam in order to claim their rights, thus limiting the space for secular approaches (Balchin 2003; Kandiyoti 1991; Zia 2009).

Furthermore, privileging religious strategies or organising on the basis of religious identity, which the BMMA does by ensuring that 70 per cent of their membership is comprised of Muslim women and that they are led by Muslim women, can give groups greater credibility to represent 'Muslim women', especially in the Indian context where the women's movement has historically been led by upper caste Hindu women. However, such strategies can also reinforce and essentialise religious differences and reinforce the notion that Muslim women form a coherent group with a common set of interests. Such strategies can also limit the possibility of building different types of alliances among those committed to justice and equality, such as those based on ideological rather than religious similarities.

The case study of the MWRN and the BMMA reflects the complexity of working within a religious framework in order to claim women's rights. While the political situation in India has left very little space for secular feminist positions, such as those that argue against religious-based personal laws and for a common civil code, the experiences of Muslim women's rights activists demonstrates the limitations of engaging proactively with religious discourses and actors. Although the nikahnama campaign and the efforts to lobby the AIMPLB have succeeded in raising awareness about Muslim women's rights, no reform has yet been made to Muslim personal laws. Furthermore, only a handful of marriages have taken place which use the model nikahnama, whether it is the progressive model put forward by women's organisations or the conservative model of the AIMPLB. The fact that women are themselves hesitant to claim their rights even if they are convinced that it is sanctioned within Islam speaks to the wider patriarchal structures that continue to exist in Indian society, which religious concepts alone cannot dismantle.

However, the emergence of the MWRN and the BMMA is itself a significant development in the Indian context, where the women's movement has historically been dominated by upper-caste Hindu women. These networks have been successful in questioning the authority of religious institutions and have highlighted the 
fact that there are multiple interpretations of Islam, including those that value justice and equality. Through their campaigning efforts, they have widened the space for debate about the relationship between Islam and women's rights, and have challenged the image of Muslim women as passive victims. The MWRN and the BMMA employ 'strategic essentialism' (Spivak 1990) by using the unifying category 'Muslim women' in order to organise for greater rights. Their strategies of selectively engaging with religious concepts and actors, reflect the changing realities and constraints of the political situation in India in which the language of secularism has been co-opted by Hindu nationalist groups, and Muslim identity has been increasingly viewed as being 'under threat'. These strategies have evolved out of decades of struggle and careful negotiation among Indian feminists, which has led some Muslim women's rights activists to the conclusion that creating alternative spaces for engaging with religious concepts, may be an effective means of claiming women's rights without denying the importance of religious identities.

\section{Notes}

1 Moghadam distinguishes between 'Islamic feminists' and 'Muslim feminists' who she argues are 'believing women' who are critical of Islamist politics and who use a mixture of religious terminology and the secular language of international human rights in calling for reform.

2 This case study is based on research I conducted in 2008 as part of the Religions and Development Research Programme (www.rad.bham.ac.uk), which is funded by the UK Department for International Development (DFID). However, the views expressed in this article are my own and do not necessarily reflect those of DFID. For a more detailed discussion of this case study within the context of Muslim women-led networks in India, see Kirmani (2009a).

3 India has a separate set of personal laws for each religious group, Hindus, Muslims, Christians and Parsis, which was put in place during the period of British colonial rule. These laws deal with issues related to the family, including marriage and inheritance.

4 The All India Muslim Personal Law Board (AIMPLB) was created in 1973 in India with the primary aim of protecting Muslim
The lesson to be learned is that religiously framed approaches may be an effective means of redefining the relationship between religion and women's rights and of undermining the authority of conservative, male-dominated institutions to represent 'the community'. However, such strategies must be accompanied by an awareness of the possible dangers of partnering with religious institutions, the limitations of using religious concepts in challenging wider social structures, and an understanding that these steps must be taken in a manner that does not essentialise or privilege religious identities by erecting boundaries between groups and particularly among those committed to the common cause of social justice and equality. The multiple approaches adopted by Muslim women's rights activists in advocating for women's matrimonial rights in India demonstrate the flexibility and dynamism that is necessary in order to effectively advocate for change in the face of evolving political and social restraints.

personal laws from government interference. Since this time, the AIMPLB has publically commented on a number of issues related to the status of Muslims in India, including prominent cases involving women's rights as well as issues such as the Babri Masjid demolition. It is a mostly male body composed of a mixture of ulema as well as lay people from various parts of the country representing different Islamic schools of thought.

5 Muslim Women (Protection of Rights on Divorce) Act 1986. Act No. 25 of 1986 dated 19 May, 1986.

6 Both networks, which are comprised of individuals and groups advocating for Muslim women's rights, emerged relatively recently, with the MWRN formed in 1999 and the BMMA in 2005.

7 Mehr is a gift given by a husband to his wife, which is obligatory in Islam. Mehr can be in the form of cash or in kind, and is intended to be an expression of appreciation as well as a form of social guarantee for women. Many argue that mehr should be given at the time of marriage, although this rarely occurs in practice in the South Asian context.

8 Parda refers to the practice of female seclusion and veiling in South Asia. 


\section{References}

Abu-Lughod, Leila (2002) 'Do Muslim Women Really Need Saving? Anthropological Reflections on Cultural Relativism and Its Others', American Anthropologist 104.3: 783-90

Adamu, Fatima (1999) 'A Double-edged Sword: Challenging Women's Oppression within Muslim Society in Northern Nigeria', Gender and Development 7.1: 56-61

Al-Hibri, Azizah (2004) 'Muslim Women's Rights in the Global Village: Challenges and Opportunities', in Haideh Moghissi (ed.), Women and Islam: Critical Concepts in Sociology, London: Routledge: 449-77

Balchin, Cassandra (2003) 'With Her Feet on the Ground: Women, Religion and Development in Muslim Communities', Development 46.4: 39-49

Bartelink, Brenda and Buitelaar, Marjo (2006) 'The Challenges of Incorporating Muslim Women's Views into Development Policy: Analysis of a Dutch Action Research Project in Yemen', Gender and Development 14.3: 351-62

Chhachhi, Amrita (1991) 'Forced Identities: The State, Communalism, Fundamentalism and Women in India', in Deniz Kandiyoti (ed.), Women, Islam and the State, New Delhi: Macmillan: 144-75

Hasan, Zoya (1998) 'Gender Politics, Legal Reform, and the Muslim Community in India', in Patricia Jeffrey (ed.), Appropriating Gender, New York: Routledge

Hasan, Zoya (1994) 'Minority Identity, State Policy and the Political Process', in Zoya Hasan (ed.), Forging Identities: Gender, Communities and the State, New Delhi: Kali for Women

Hashim, Iman (1999) 'Reconciling Islam and Feminism', Gender and Development 7.1: 7-14

Hassan, Riffat (2002) 'Is Islam a Help or Hindrance to Women's Development?', in J. Meuleman (ed.), Islam in the Era of Globalization: Muslim Attitudes towards Modernity and Identity, London: Routledge: 189-209

Kandiyoti, Deniz (1991) 'Islam and Patriarchy: A Comparative Perspective', in Nikki R. Keddie and Beth Baron (eds), Women in Middle Eastern History: Shifting Boundaries in Sex and Gender, New Haven: Yale University Press: 23-44

Katakam, Anupama (2005) 'Reluctant Reform', Frontline 22.11, www.hinduonnet.com/fline/ f12211/stories/20050603003303600.htm (accessed 1 June 2009)

Kirmani, Nida (2009a) Beyond the Religious Impasse: Mobilizing for Muslim Women's Rights in
India, Religions and Development Research Programme, Working Paper 35, University of Birmingham: International Development Department

Kirmani, Nida (2009b) 'Deconstructing and Reconstructing "Muslim Women" through Women's Narratives', Journal of Gender Studies 18.1: 47-62

Kishwar, Madhu (1998) 'Pro-Women or AntiMuslim? The Shah Bano Controversy', in Madhu Kishwar (ed.), Religion at the Service of Nationalism, Delhi: Oxford University Press

Kumar, Radha (1994) 'Feminism Faces Fundamentalism in India', Agenda 21: 81-92

Lateef, Shahida (1998) 'Muslim Women in India: a Minority Within a Minority', in Herbert Bodman and Nayereh Tohidi (eds), Women in Muslim Societies: Diversity within Unity, Boulder: Lynne Rienner

Mirza, Qudsia (2008) 'Islamic Feminism and Gender Equality', ISIM Review 21: 30-1

Moghadam, Valentine (2004) Towards Gender Equality in the Arab/Middle East Region: Islam, Culture and Feminist Activism, UNDP Human Development Report Occasional Paper, http://hdr.undp.org/docs/publications/ background_papers/2004/HDR2004_Valentine _Moghadam.pdf (accessed 4 June 2009)

Pearson, Ruth and Tomalin Emma (2008) 'Intelligent Design?: A Gender-sensitive Interrogation of Religion and Development', in G. Clarke and M. Jennings (eds), Development, Civil Society and Faith-based Organisations: Bridging the Sacred and the Secular, Basingstoke: Palgrave Macmillan: 46-71

Phillips, Ann (2009) 'Religion: Ally, Threat or Just Religion' (draft working paper), Geneva: United Nations Research Institute for Development

Spivak, Gayatri (1990) Postcolonial Critic: Interviews, Strategies, Dialogues, New York: Routledge

UNFPA (2004) Culture Matters: Working with Communities and Faith-based Organisations, Case Studies from Country Programs, New York: United Nations Fund for Population Activities

Wadud, Amina (2007) Inside the Gender Jihad: Women's Reform in Islam, Oxford: Oneworld Publications

Wajihuddin, Mohammed (2008) 'This Qazi is a Woman', The Times of India, 12 October, http://timesofindia.com/This-Qazi-is-a-woman/ articleshow/3585185.cmc (accessed 29 May 2009) 
Winter, Bronwyn (2001) 'Fundamental Misunderstandings: Issues in Feminist Approaches to Islamism', Journal of Women's History 13.1: 9-41
Zia, Afiya S. (2009) 'The Reinvention of Feminism in Pakistan', Feminist Review 91.1: 29-46 